
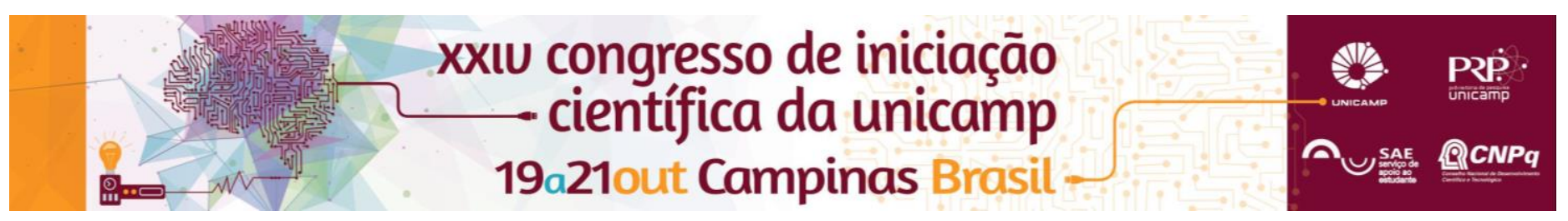

\title{
Salivar cortisol from undergraduated students
}

\section{Samantha Mc Fadden*, Érica A. M. Camargo, Fernando Canova, Priscila C. Silva, Filipy Borghi, Pedro Fidelis, Aglécio L. de Souza, Maria Silvia M. Pires de Campos, Dora M. Grassi Kassisse.}

\begin{abstract}
Cortisol is a hormone that presents ritmicity, with higher levels in the morning and lower levels at night. Alterations in the amounts and ritmicity of cortisol production are mainly due to chronic distress. We evaluate the cortisol levels from undergraduate students from two different studies in development in Labeest. Samples were taken in different moments: in the morning and before sleep. The students show ritmicity in cortisol production, with lower levels at night.
\end{abstract}

Key words: Cortisol ritmicity, undergraduate students.

\section{Introduction}

Cortisol is a steroid hormone that presents ritmicity, with higher levels in the morning and lower levels at night. Alterations in the total amounts and ritmicity of cortisol production are mainly due to chronic distress ${ }^{1}$. This project aimed to evaluate the cortisol salivary levels from undergraduate students. The students were from private and public schools and are the control group from two different studies in development in Labeest (CAAE: 24537613.2.0000.5404 and 41225614.8.0000.5404. Saliva samples were taken in two different moments: in the morning (6 a.m.) and before sleep (11 p.m.). It was evaluated by ELISA assay ${ }^{1,2}$. Statistical analysis was done using Prisma software, and as the data was not normal, analysis was performed using Wilcoxon signed rank test or Mann Whitney test, paired or unpaired study.

\section{Results and Discussion}

We evaluated cortisol amounts from 62 volunteers. The population in this study was divided in 11 men and 51 women, 18 from full and 44 from night courses, 39 from private and 23 from public university. All of then presented lower cortisol levels before sleep, showing ritmicity (Figure 1).

Figure 1- Cortisol salivary levels in the morning (6 a.m.) and before sleep (11 p.m.) from undergraduate students.

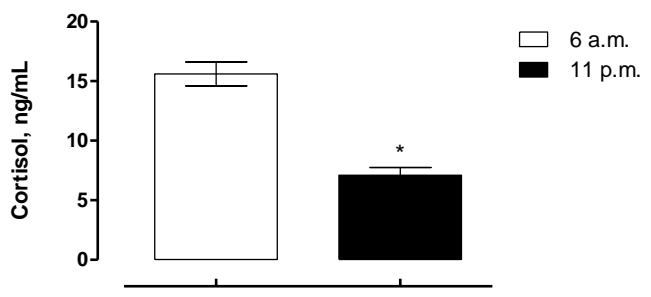

${ }^{*} \mathrm{p}<0.0001$, Wilcoxon signed rank test

All analysis performed in cortisol levels in this study did not show any difference, even for students from night period (Figure 2).

Figure 2- Cortisol salivary levels in the morning (6 a.m.) and before sleep (11 p.m.) from sub populations undergraduate students
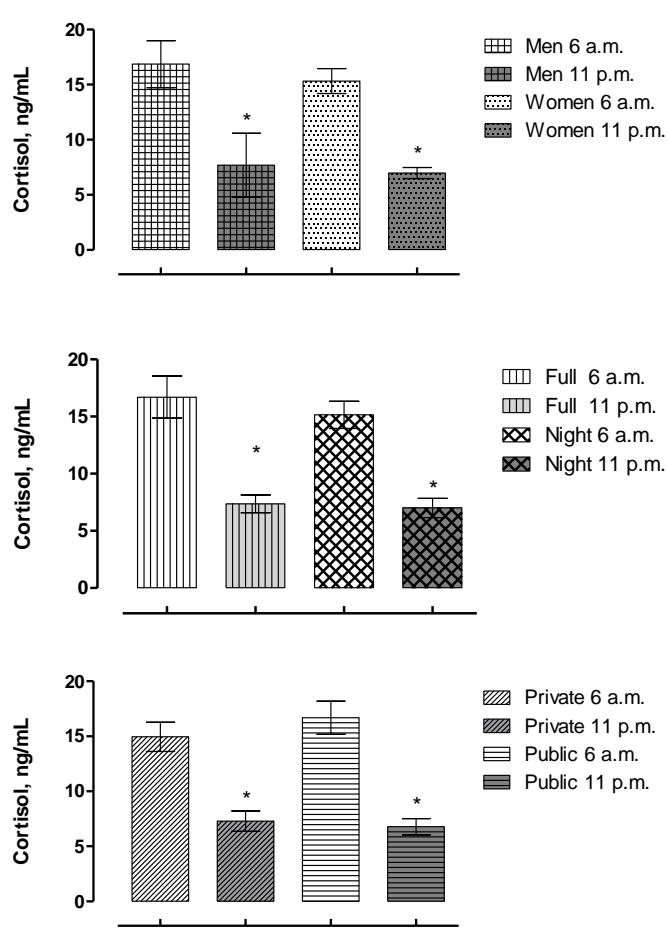

${ }^{*} \mathrm{p}<0.0001$ Wilcoxon signed rank test

\section{Conclusions}

In our study, all volunteers show cortisol ritmicity and none variable interfered at ritmicity of these undergraduate students.

\section{Acknowledgement}

Thanks to all volunteers, Capes, Fapesp and Faepex.

${ }^{1}$ Batista, J. C., A. L. Souza, H. A. Ferreira, F. Canova, and D. M. GrassiKassisse, 2015, Acute and Chronic Effects of Tantric Yoga Practice on Distress Index: J Altern Complement Med. vol 21, edição 11: 681685

${ }^{2}$ Rocha, M. C. P., M. M. F. Martino, D. Grassi-Kassisse, and A. L. Souza, 2013 , Stress among nurses: an examination of salivary cortisol levels on work and day off: Revista Da Escola De Enfermagem Da Usp, v. 47, p. 1187-1194. 